\title{
PEMANFAATAN MEDIA SOSIAL PADA GAWAI SEBAGAI MEDIA PEMBELAJARAN
}

\section{Wanda Monika Putri}

E-mail: wandamonikaaputrii@gmail.com

*Program Studi Pendidikan Bahasa dan Sastra Indonesia, Universitas Maritim Raja Ali Haji, Kepulauan Riau, Indonesia

\begin{abstract}
Abstrak
Gawai yang saat ini kerap kali digunakan menjadi fasilitas penunjang belajar siswa, yang sangat memudahkan guru (pendidik) dan siswa (peserta didik) dalam proses kegiatan pembelajaran, kemudian akses informasi yang mempermudah melakukan sejumlah aktivitas. Pada saat COVID-19 yang masih merajalela menjadikan seluruh siswa (peserta didik) harus melaksanakan proses belajar dari rumah atau secara daring (dalam jaringan), suatu hal ini membuat pihak sekolah membuat kesepakatan untuk memanfaatkan media sosial sebagai media untuk pembelajaran melalui gawai tersebut. Berbagai aplikasi-aplikasi pendukung dalam gawai memudahkan guru (pendidik) dalam proses belajar dan mengajar, sehingga media pembelajaran dari gawai ini dijadikan alternatif yang sangat fleksibel dalam membantu proses pembelajaran siswa saat ini.Berbagai tuntutan dalam dunia pendidikan juga tidak lepas dari kegiatan belajar, bukan tanpa alasan pihak sekolah membuat aturan baru untuk penggunaan media sosial sebagai media dalam proses kegiatan pembelajaran.
\end{abstract}

\section{Kata kunci: media sosial, gawai, media pembelajaran}

\section{PENDAHULUAN}

Menurut Kamus Besar Bahasa Indonesia (KBBI) kata 'gawai' berarti peranti elektronik atau mekanik dengan fungsi praktis. Gawai dirancang sebagai alat multifungsi yang dapat memudahkan pekerjaan manusia, memudahkan memperoleh informasi, dan mengolah informasi dengan efektif dan efisien dalam aktivitas sehari-hari. Gawai ini juga berperan penting dalam dunia pendidikan dan proses pembelajaran. Saat ini, media sosial yang terdapat di gawai seperti WhatsApp, Youtube, dan Google Classroom berperan sebagai media dalam pembelajaran oleh masyarakat saat ini. Pemanfaatan media sosial pada gawai digunakan guru sebagai sarana memberikan informasi terkait dengan materi pembelajaran, pelaporan hasil tugas akhir siswa, pencarian materi dalam pembelajaran, dan lain sebagainya. 
Di zaman yang serba teknologi ini, mengharuskan pendidik untuk lebih aktif dalam mengetahui perkembangan, salah satunya dengan memberikan sumber belajar yang tidak sebatas dari buku paket yang diberikan pihak sekolah, karena dengan adanya tampilan baru yang menarik akan menciptakan semangat baru bagi peserta didik untuk rajin dalam proses pembelajaran yang dilakukannya.

\section{HAKIKAT PEMBELAJARAN}

Pembelajaran adalah proses interaksi peserta didik bersama lingkungannya, yang menghasilkan perubahan bentuk perilaku menuju arah lebih baik dari sebelumnya (Arfani, 2018: 88). Untuk itu, media pembelajaran adalah segala sesuatu yang dapat digunakan untuk menyalurkan informasi berupa pengetahuan yang dapat diterima oleh peserta didik.

Bersama penggunaan media diharapkan dapat member peningkatan pada prestasi serta motivasi dalam belajar siswa (Kuswanto \& Radiansah, 2018: 15). Ada sejumlah cara menjadikan guru lebih kreatif dalam menciptakan suatu proses pembelajaran, salah satu diantaranya adalah pemanfaatan media pembelajaran untuk kegiatan proses belajar (Kuswanto \& Radiansah, 2018: $15)$.

Pembelajaran yang baik adalah pembelajaran yang dapat merancang segala media yang dapat dipahami dan menarik, karena semenarik apapun materi yang disajikan jika bahasa yang digunakan tidak dipahami akan menjadikan kekeliruan dalam tujuan penyampaian. Namun, jika materi yang disajikan dalam media pembelajaran mudah dipahami dan menarik minat siswa, maka akan membangkitkan semangat siswa untuk mencari tahu lebih terkait materi yang telah ia pelajari.

\section{SARANA PENDUKUNG}

\section{a. Media Sosial}

Media sosial adalah sebagai media dalam jaringan yang mana penggunanya bisa dengan mudah ikut berpartisipasi, membagikan, serta menciptakan sesuatu seperti blog, jejaring sosial,dan forum lainnya dalam dunia maya (Ainiyah, 2018: 223).

Media sosial merupakan sebuah media untuk bersosialisasi dengan orang yang dilakukan secara online sehingga sangat memungkinkan manusia untuk saling berinteraksi tanpa dibatasi oleh ruang dan waktu. 
Media sosial atau aplikasi yang telah disajikan dalam gawai ini banyak memilki manfaat, tergantung dari pengguna yang dapat memanfaatkan pada hal-hal yang dibutuhkan dan bernilai positif, salah satunya adalah untuk sarana memfasilitasi proses pembelajaran yaitu untuk mengirim tugas, mencari materi, mendapatkan informasi, dan sebagainya yang berhubungan dengan kebutuhan pendidik dan peserta didik.

Untuk itu, berikut beberapa media sosial yang terdapat di gawai dan telah digunakan sebagai sarana media pembelajaran:

a) WhatsApp

WhatsApp adalah suatu media komunikasi yang tidak lagi asing ditelinga masyarakat, bahkan cukup populer dan merupakan fitur aplikasi dalam gawai yang digunakan bagi kepentingan pribadi ataupun sosial (Salsabila dkk., 2020: 5).

WhatsApp adalah aplikasi pesan yang instan untuk gawai. Hampir semua masyarakat menggunakan aplikasi ini dalam kehidupan sehari-hari. Tanpa terkecuali, aplikasi ini juga digunakan dalam proses pembelajaran saat dalam jaringan (daring) yang diterapkan di masa pandemi.

b) Youtube

Youtube merupakan aplikasi layanan berbagi video dimana para pengguna dapat mengunggah, memuat, menonton, dan berbagi klip video. Dalam situs web ini yang terdapat di gawai juga bisa dijadikan sarana media pembelajaran. Siswa dapat mencari dan mengolah informasi pembelajaran dengan mudah dari berbagai sumber kreator yang ada.

c) Google Classroom

Google Classroom adalah platform gratis yang diciptakan untuk mempermudah kegiatan pembelajaran bagi pendidik dan peserta didik.

Google Classroom dimanfaatkan oleh semua ruang lingkup dalam dunia pendidikan berbeda baik tingkat SD, SMP/MTs, SMA/MAN/SMK, dan Perguruan Tinggi (Salsabila dkk., 2020: 4).

Penggunaan Google Classroom ini sudah marak digunakan dalam proses pembelajaran di tiap tingkat satuan pendidikan, sehingga memudahkan guru (pendidik) dalam memberikan, menyajikan, dan mengolah materi pembelajaran 
bagi siswa, serta memudahkan siswa untuk mempelajari dan menyerahkan hasil pembelajaran berupa latihan atau tugas yang telah diberikan.

\section{KESIMPULAN}

Pemanfaatan media social pada gawai sebagai media untuk pembelajaran saat ini sangat banyak diminati oleh masyarakat di era milenial. Apalagi saat masa COVID-19 ini, pembelajaran yang dilakukan dirumah justru sangat mengharuskan siswa untuk menggunakan gawai sebagai alternatif lain dalam membantu proses pembelajaran mereka. Saat ini, dalam dunia pendidikan sangat penting bagi setiap manusia untuk menciptakan manusia yang berkualitas, menanamkan pengetahuan, kematangan pola pikir, serta emosional.

Gawai dimanfaatkan sebagai sarana penunjang belajar siswa, memudahkan siswa dalam proses pembelajaran, kemudian mengakses informasi untuk mempermudah melakukan aktivitas. Meskipun gawai memiliki sisi positif, bukan berarti tidak ada kemungkinan juga jika bermain gawai menimbulkan sisi negatif. Oleh karena itu, diperlukan sikap bijak dalam bermain gawai tersebut dalam menjadikan gawai sebagai sarana untuk media pembelajaran agar tidak menimbulkan akibat yang fatal bagi siswa yang menggunakan gawai tersebut. Sisi positif yang ditimbulkan gawai ini tergantung dari penggunaan setiap orang.

Adanya berbagai aplikasi-aplikasi pendukung dalam gawai memudahkan pendidik dalam melakukan proses belajar-mengajar, memudahkan penyebaran materi pada siswa, sehingga siswa lebih aktif dan kritis terhadap materi pembelajaran yang telah diberikan maupun yang akan datang. 


\section{REFERENSI}

Ainiyah, N. (2018). Remaja Milenial dan Media Sosial: Media Sosial sebagai Media Informasi Pendidikan bagi Remaja Milenial. Jurnal Pendidikan Islam Indonesia. https://doi.org/10.35316/jpii.v2i2.76.

Arfani, L. (2018). Mengurai Hakikat Pendidikan, Belajar dan Pembelajaran. Pelita Bangsa Pelestari Pancasila, 11(2), 81-97. https://pbpp.ejournal.unri.ac.id/index.php/JPB/article/view/5160.

Kuswanto, J., \& Radiansah, F. (2018). Media Pembelajaran Berbasis Android Pada Mata Pelajaran Sistem Operasi Jaringan Kelas XI. Jurnal Media Infotama, 14(1), 15-20. https://jurnal.unived.ac.id/index.php/jmi/article/view/467.

Salsabila, U.H., Lestari, W.M., Habibah, R., Andaresta, O., \& Yulianingsih, D. (2020). Pemanfaatan Teknologi Media Pembelajaran di Masa Pandemi Covid-19. Jurnal Pendidikan Dasar. http://dx.doi.org/10.30742/tpd.v2i2.1070. 


\section{*Data Penulis}

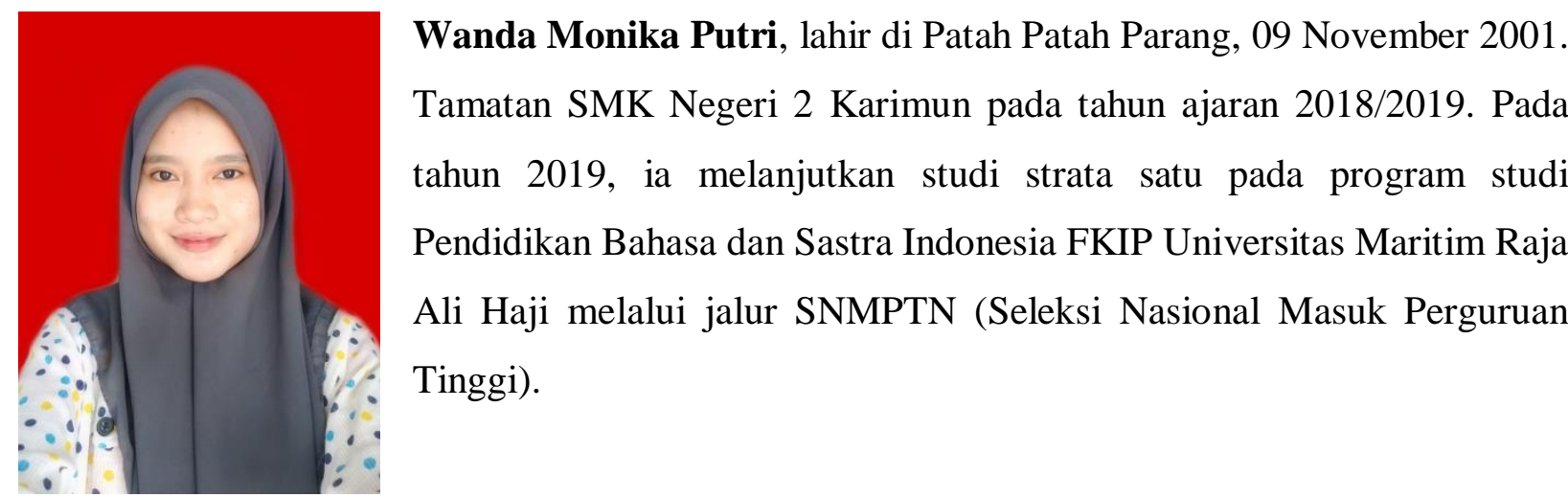

Kontak:

Hp/WA :-

Email : wandamonikaaputrii@gmail.com 